\title{
Die betekenis en retoriese funksie van Galasiërs 3:10
}

\author{
D.F. Tolmie
}

Departement Nuwe Testament

Universiteit van die Vrystaat

BLOEMFONTEIN

E-pos: tlgdt@rs.uovs.ac.za

\begin{abstract}
The meaning and rhetorical function of Galatians 3:10

The interpretation of Galatians $3: 10$ is one of the exegetical dilemmas in the Letter to the Galatians. In this article the various ways in which scholars explain the meaning of this verse are classified in terms of the following three aspects: 1 . The meaning of the expression ö $\sigma o \iota \epsilon^{\prime} \xi \xi{ }^{\prime \prime} \rho \gamma \omega \nu \nu{ }^{\prime} \mu o v ; 2$. The meaning of the ex-

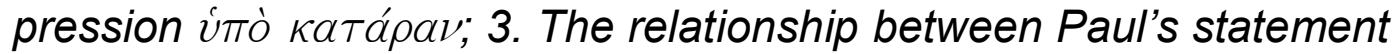
in verse 10a and the quotation in verse 10b. In each instance the author summarises the various possibilities and justifies his own choice. The rhetorical function of Galatians 3:10 within the pericope 3:6-14 is discussed and it is argued that it is used rhetorically, both for the vilification (of the opponents) and as a rhetorical threat (to the readers).
\end{abstract}

\section{Inleiding}

Galasiërs 3:10 kan met reg as een van die moeilikste teksverse in die Brief aan die Galasiërs beskryf word. Dit vorm deel van 'n reeks argumente uit die Ou Testament wat Paulus in Galasiërs 3:6-14 gebruik met die doel om die Galasiërs te probeer oortuig dat dit wat sy opponente aan hulle verkondig, verkeerd is en dat sý weergawe van die evangelie korrek is. Een van die sake wat klaarblyklik in dié debat baie belangrik was, is die vraag aan watter kwalifikasies ' $n$ mens moet voldoen om een van die "kinders van Abraham" te wees. Heel waarskynlik het Paulus se opponente juis die voorbeeld van Abraham as argument gebruik om die Christene in Galasië te oortuig om hulle standpunt te aanvaar. So byvoorbeeld kon hulle die feit dat Abraham besny is, as motivering voorhou waarom die Galasiërs besny moes word. Gevolglik probeer Paulus in Galasiërs 3:6-9 die argumente van sy 
opponente weerlê met sy eie interpretasie van Abraham. Volgens Paulus kan 'n mens op grond van die geskiedenis van Abraham sien dat mense kinders van Abraham word as hulle Abraham se voorbeeld volg en glo. Op dié manier verkry hulle dan die seën wat God aan Abraham beloof het.

Direk nadat Paulus na "seën" verwys het, slaan hy dan in Galasiërs 3:10 oor na die ander kant van die saak, naamlik "vloek". 1 Hy sê dat

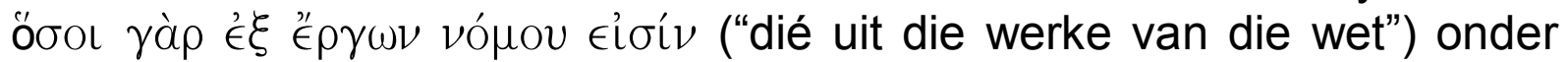
die vloek is. Dié stelling bevestig hy dan deur 'n aanhaling uit die Ou

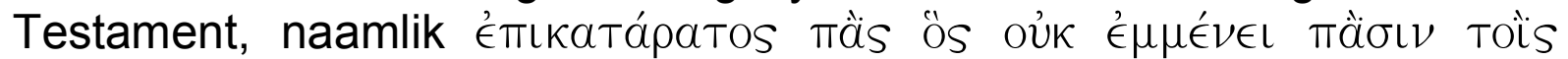

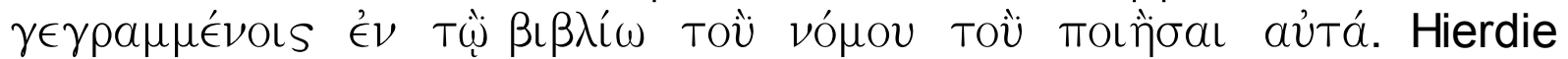
aanhaling kom uit Deuteronomium 27:26, maar verskil ietwat van die

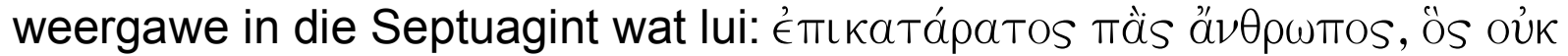

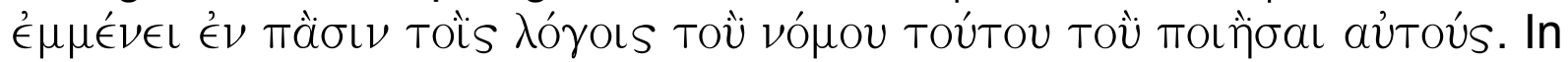
vergelyking met die Septuagint-weergawe laat Paulus $\alpha{ }^{\prime} \nu \rho \omega \omega \pi$ os weg,

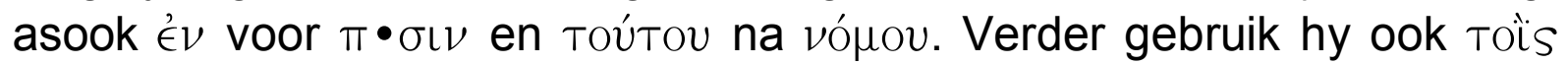

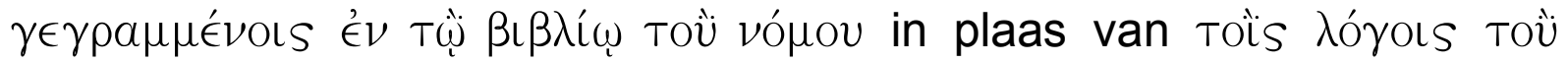
vónov. Omdat hierdie verskille die gevolg kan wees van die feit dat Paulus uit sy geheue aanhaal of selfs 'n ander teks gebruik het as dit wat ons tot ons beskikking het, ${ }^{2}$ kan 'n mens nie soos Koch (1986:120) en Eckstein (1996:124) aanvaar dat hy doelbewus dié veranderinge aangebring het nie. Dít is egter nie die eintlike saak waaroor uitleggers 'n verskil van opinie het nie. Die verskil van opinie gaan oor hoe vers 10 geïnterpreteer moet word. Alhoewel 'n mens redelik maklik die basiese strekking van Paulus se woorde in hierdie vers kan begryp, is dit die fynere aspekte van sy argument wat op verskillende maniere geïnterpreteer kan word. In hierdie artikel word 'n oorsig van die verskillende interpretasies gegee, 'n eie keuse gemaak en die retoriese funksie van hierdie vers binne Paulus se argument bespreek.

\section{Die interpretasie van Galasiërs 3:10}

Oor die interpretasie van Galasiërs 3:10 het daar al baie publikasies verskyn. Alhoewel baie daarvan herhalend van aard is, is dit nogtans so dat daar al 'n wye reeks interpretasiemoontlikhede van vers 10 aangebied is. Wat hier volg, is ' $n$ poging om die verskillende interpretasiemoontlikhede so ver as moontlik te sistematiseer. Alhoewel dit

$1 \quad$ Hübner (1993:75) wys tereg daarop dat die manier waarop Paulus hier die begrippe seën en vloek gebruik, 'n goeie aanduiding is van hoe diep sy denkkategorieë deur die Ou Testament beïnvloed is, want dié twee kategorieë is "fundamentale Existenzwesen" in die Ou Testament.

2 Volgens Betz (1979:145) kom verskille soortgelyk aan dié wat in Paulus se weergawe voorkom, ook in sommige ander LXX-tekstradisies voor. 
nie altyd moontlik is om oorvleueling tussen standpunte uit te skakel nie, is gepoog om dit sover as moontlik te vermy. Myns insiens kan die belangrikste verskille in die interpretasie van hierdie vers teruggevoer word na drie basiese vrae waarop eksegete verskillende en dikwels opponerende antwoorde gee. Dié drie vrae en die antwoorde wat daarop gegee word, word vervolgens bespreek:

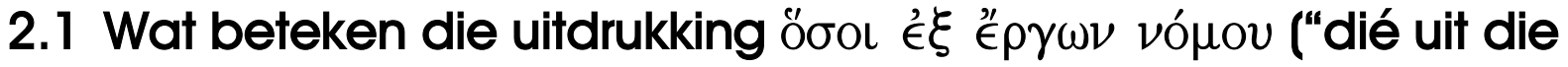 werke van die wet")?}

'n Mens kan die antwoorde wat eksegete op hierdie vraag gee, klassifiseer in terme van die volgende twee opsies:

- Talle eksegete interpreteer Paulus se woorde as 'n verwysing na sy opponente ten opsigte van hulle basiese vertrekpunt, naamlik dat hulle die nakoming van die wet (oor die algemeen) as van beslissende belang in 'n mens se verhouding tot God beskou. Om enkele voorbeelde te gee: Burton (1962:165) interpreteer dié begrip as 'n beskrywing van Paulus se opponente as "men whose standing and character proceed from ( statutes". Schlier (1971:132) se verduideliking van dié uitdrukking dui in dieselfde rigting: "... die Menschen, die das Prinzip ihrer Existenz in den Gebotserfüllungen haben". Martyn (1998:308) sê min of meer dieselfde. Volgens hom is hulle mense wat hulle identiteit verkry vanuit die nakoming van die wet. Soortgelyke standpunte word gehuldig deur talle ander eksegete, onder wie die volgende: Lietzmann (1971: 17), Mussner (1977:223), Becker (1981:36), Rohde (1989:140), Betz (1979:145) en Eckstein (1996:122). Alhoewel 'n mens fynere nuanseverskille sou kon aandui in die presiese wyse waarop hierdie eksegete die begrip uitlê, stem hulle almal breedweg daaroor saam dat dit te doen het met die uitermate klem wat Paulus se opponente in hulle godsdiens op die nakoming van die wet geplaas het.

- Hierteenoor is daar 'n tweede standpunt waarvolgens die uitdrukking in 'n baie meer beperkte sin verstaan moet word. Van hierdie groep is Dunn (1990:214-241; kyk ook Dunn 1993:170-173) seker die bekendste. In aansluiting by die sogenaamde "nuwe perspektief" op

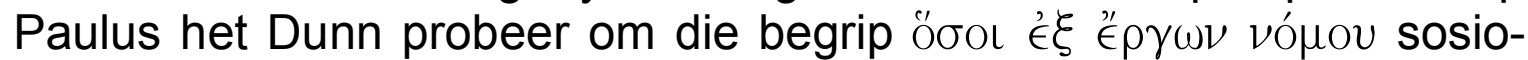
logies te belig. Hy kom dan tot die gevolgtrekking dat 'n mens 'n onderskeid moet maak tussen die "onderhouding van die wet" en "dié wat uit die werke van die wet is" (die uitdrukking wat in Galasiërs 3:10 - en ook elders in Galasiërs gebruik word). Volgens hom verwys laasgenoemde na iets anders en iets minder as die nakoming van die

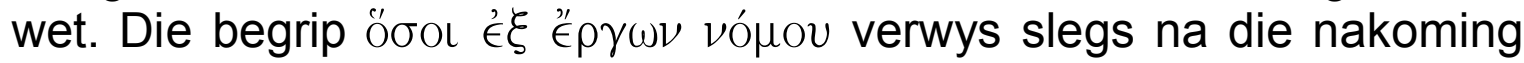
van spesifieke tipies Joodse praktyke wat deur die wet voorgeskryf 
word, byvoorbeeld die besnydenis en die Joodse eetwette, maar dan spesifiek gemotiveer deur 'n onnodige klem op die onderskeid tussen Jode en heidene. Soos Dunn (1993:172) dit stel:

It thus denotes those whose identity was grounded on works of the law, whose relationship with God was characterized and determined by works of the law, in contrast to those characterized by faith. And 'works of the law'... is Paul's code for those requirements of the law in particular which brought to sharpest focus Israel's claim to be distinctive from others as God's covenant people.

Volgens Dunn val Paulus in Galasiërs dus slegs 'n bepaalde verkeerde verstaan van die wet aan, naamlik die "uit die werke van die wet-wees" omdat dit volgens hom nie dieselfde is nie en dus minder is as die volle nakoming van die wet. Dit behels dan spesifiek dié wette wat fokus op die onderskeid tussen Jode en heidene, veral wette wat te doen het met die besnydenis en die Joodse eetwette wat in Galasiërs 'n belangrike rol speel. Dunn se interpretasie word gesteun deur Cranford (1994:249250), Bonneau (1997:66-68) en Young (1998:80-81).

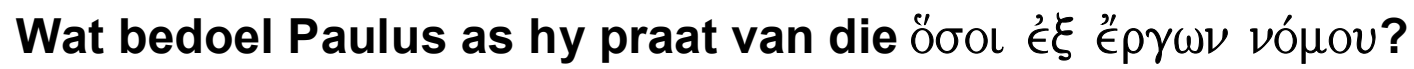

Myns insiens oortuig die interpretasie van Dunn en die ander wat met hom saamstem, nie werklik nie as gevolg van die volgende redes:

- Dit is moeilik om te aanvaar dat Paulus werklik so 'n fyn tegniese onderskeid tref tussen dié wat die wet "nakom" en dié wat "uit die werke van die wet is", asof eersgenoemde die diepere beginsels van die wet uitleef en laasgenoemde bloot vaskyk teen die oppervlakkige onderskeidings wat die wet tref tussen Jood en nie-Jood. Uit die res van Galasiërs lyk dit ook nie asof Paulus die onderskeid wat Dunn tref, werklik konsekwent handhaaf nie. In Galasiërs 2:16 wys hy wel die regverdiging "deur die werke van die wet" af, maar slegs 'n paar reëls verder (2:21) wys hy regverdiging "deur die wet" af (en nie spesifiek regverdiging deur "die werke van die wet" nie). 'n Mens sou ook kon wys op Galasiërs 3:11 waar Paulus ook regverdiging "deur die wet" afwys.

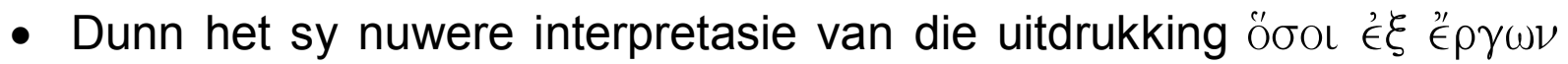
$\nu$ ó $\mu$ ov aangebied as 'n insig wat vanuit 'n sosiologiese perspektief op die teks sou kom, maar dit is insiggewend dat Esler (1998:182-183) wat 'n baie goed gefundeerde sosiologiese perspektief op Galasiërs bied, nie met Dunn saamstem nie. Esler toon aan dat dit vanuit sosiale identiteitsteorie ("social identity theory") hoogs onwaarskynlik is dat ' $n$ groep hulleself slegs sou definieer (soos Dunn beweer) in terme van overte tekens en nie ook in terme van waardeoriënterings 
nie. Hy wys ook daarop dat dit hoogs onwaarskynlik is dat 'n groep slegs sou fokus op die openbare aspekte van die sosiale grens tussen hulle groep en ander groepe sonder om die private aspek in ag te neem.

In die lig van bogenoemde blyk dit dat Dunn se interpretasie nie aanvaar kan word nie. Dit lyk meer verantwoord om die tradisionele interpretasie

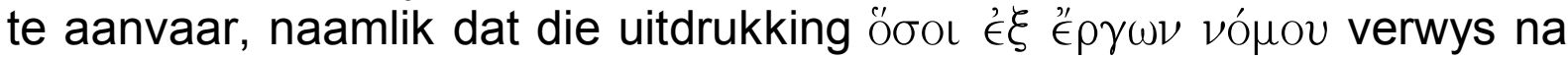
Paulus se opponente (en die Christene in Galasië wat hulle standpunte aanvaar) as 'n groep mense wat die nakoming van die wet (oor die algemeen) as van deurslaggewende belang beskou vir 'n mens se verhouding tot God.

\subsection{Wat beteken die uitdrukking ưтò катápav ("onder 'n vloek")?}

Weer eens kan die manier waarop eksegete hierdie vraag beantwoord tot twee basiese standpunte gereduseer word:

- Baie eksegete is van mening dat Paulus bedoel dat diegene wat die nakoming van die wet die vertrekpunt van hulle godsdiens maak, daardeur die gevaar loop om vervloek te word. So verduidelik Longenecker (1990:117) byvoorbeeld Paulus se logika in hierdie gedeelte soos volg: Paulus waarsku die Galasiërs dat hulle besig is om 'n totaal verkeerde keuse te maak deur te probeer om die wet na te kom (soos wat sy opponente hulle voorsê om te doen), want deur die wet te aanvaar, aanvaar hulle ook die dreigement wat altyd saamgaan met die nakoming van die wet. Dit behels naamlik dat hulle vervloek sal word as hulle nie die wet nakom nie. Hierdie interpretasie van úmò катápav word ook verkies deur ander eksegete, byvoorbeeld Mussner (1977:224), Stanley (1990:500), Braswell (1991:76) en Smit (1984:214).

- Daar is egter ook ander eksegete wat van mening is dat Paulus nie bloot na 'n dreigende vloek verwys nie, maar praat van 'n vloek wat Israel volgens hom alreeds ervaar. Volgens hulle bedoel hy dat die Galasiërs deur die nakoming van die wet hulleself plaas onder dieselfde vloek as wat Israel op daardie stadium besig was om te ervaar. Hierdie siening kan teruggevoer word na die studie wat Noth (1957: 155-171 - oorspronklik gepubliseer in 1938) gedoen het en waarin hy argumenteer dat Paulus eintlik Deuteronomium 27:26 korrek interpreteer volgens die bedoeling wat die Deuteronomistiese redakteurs oorspronklik daarmee gehad het. Volgens hulle siening was die vloek waarvan in Deuteronomium 26-28 gepraat word, alreeds 'n werklikheid toe hulle hulle geskiedswerk afgesluit het: omdat Israel nie die wet nagekom het nie, het die vloek in vervulling 
gegaan en het Israel onder die vloek geleef. Volgens Noth huldig Paulus 'n soortgelyke siening in Galasiërs 3:10: die Jode leef onder die vloek van die wet, en deur die wet te aanvaar, is die Galasiërs besig om onder dieselfde vloek in te beweeg.

Verskeie moderne navorsers vind aansluiting by Noth se interpretasie, gewoonlik met 'n effense wysiging daarvan.

Thielman (1989:68-69) toon enkele swak punte in Noth se uiteensetting aan, byvoorbeeld die feit dat Noth verkeerdelik aanvaar dat Deuteronomium geen hoop vir Israel voorhou nie. Nietemin aanvaar Thielman Noth se standpunt dat die vloek waarvan Deuteronomium praat, in vervulling gegaan het, en neem hy selfs aan dat dit algemene kennis in Paulus se tyd was dat Israel ongehoorsaam was en dat die vloek in vervulling gegaan het. Paulus sou dan in vers 10 sinspeel op hierdie algemene kennis.

Eckstein (1996:125-129) stem in wese saam met Noth, maar toon aan dat Noth een grondliggende verskil tussen Paulus en Deuteronomium misgekyk het, naamlik dat Deuteronomium ook rekening hou met die moontlikheid dat daar by Israel 'n gesindheidsverandering kan kom: “... eine von Gott eröffnete Möglichkeit der Veränderung ... nähmlich durch Jahwes Erbarmen ... zu Umkehr, Beschneidung des Herzens und neues Gehorsam" (Eckstein, 1996:127). Hierteenoor sien Paulus die wet alleen as God se veroordelende spreke.

Volgens Wright (1992:145-147) handel Deuteronomium 27-30 nie soseer oor die oortredings van individue nie, maar oor die vraag wat gebeur as die volk in sy geheel in gebreke bly om die hele wet na te kom. Volgens Wright is Deuteronomium 27-30 se antwoord hierop nie die tipiese Rabbynse skema van bekering, offer, en vergifnis nie, maar wel dat daar oordeel oor die hele volk sal kom (die ballingskap) wat later gevolg sal word deur God se genade. Paulus sou dan in Galasiërs veronderstel dat Israel nog steeds hierdie vloek ervaar en dit as argument gebruik dat dié wat nie die wet ten volle nakom nie, deelkry aan hierdie vloek.

Myns insiens is die deurslaggewende saak wanneer 'n mens moet kies tussen Noth (en dié wat sy standpunt verfyn) se interpretasie van die uitdrukking "onder die vloek" en die ander moontlikheid (dat dit gaan oor 'n dreigende vloek), die vraag of daar ander aanduidings is by Paulus en ook by die Judaïsme van sy tyd dat hulle van mening was dat die Joodse volk onder 'n vloek gebuk gegaan het. Soos Dunn (1993:172) tereg uitwys, moet 'n mens op hierdie vraag "nee" antwoord. As 'n mens let op gedeeltes soos Romeine 2:17-20, 10:2-3, Galasiërs 1:13-14 en Filip- 
pense 3:6, kry 'n mens allermins 'n blik op die Judaïsme as synde 'n groep mense wat dink dat hulle nog steeds onder die vloek van die ballingskap gebuk gaan. Verder, indien Noth korrek sou wees en die Judaïsme gekenmerk sou word deur 'n bewustheid van die vloek waaronder hulle moet leef omdat die hele volk nie die wet nagekom het nie, is dit 'n vraag hoekom daar nogtans so 'n sterk strewe by sommige groepe binne die Judaïsme was om die wet so nougeset as moontlik na te kom. Wat sou die sin daarvan wees as Israel reeds onderworpe was aan die vloek wat saamgaan met ongehoorsaamheid? Dit lyk dus na 'n verantwoorde keuse om die interpretasie van Noth (en andere) af te wys en eerder te aanvaar dat Paulus die uitdrukking "onder 'n vloek" gebruik om te verwys na 'n dreigende vloek, die vloek wat oor elkeen kom wat nie stiptelik doen wat die wet sê nie.

\subsection{Hoe moet die verband tussen Paulus se stelling in vers 10a en die aanhaling in vers $10 \mathrm{~b}$ verstaan word?}

Bogenoemde vraag kan ook anders gestel word, naamlik in watter sin het Paulus die aanhaling as 'n bewys van sy voorafgaande stelling beskou?

In die antwoorde wat eksegete op hierdie vraag gee, loop die eksegetiese paaie werklik uiteen. Van die talle verskillende antwoorde wat gegee word, lyk dit asof die volgende die belangrikste is:

- Talle eksegete, byvoorbeeld Lietzmann (1971:19), Burton (1962:164), Thurén (2000:92), Longenecker (1990:117), Sass (1995:284) en Schreiner (1984:151-160 en 1985:245-278), is van mening dat Paulus aanvaar dat dit prinsipieel onmoontlik is vir enige mens om die wet na te kom, en dat hy gevolglik die woord mầotv in die aanhaling beklemtoon om hierdie aspek te benadruk. Daarmee wil hy dan sê dat enige persoon wat probeer om die wet na te kom, onder 'n vloek kom omdat hy/sy dit nooit sal regkry om alles te doen wat die wet vereis nie.

- 'n Ander standpunt wat nou verwant is aan bogenoemde, word gehuldig deur eksegete wat sê dat Paulus nie noodwendig bedoel dat dit - prinsipieel gesien - vir mense onmoontlik is om die wet na te kom nie, maar dat dit wel in die praktyk (de facto) so is dat mense nooit die wet nakom nie. Paulus sou dan van hierdie feitelike situasie uitgaan as hy sê dat almal wat die wet probeer nakom, onder die vloek is. Soos Hübner (1993:75) dit stel: "Paulus hält sich aber an das Faktum der Nichterfüllung. Eine Erklärung dieses Faktums bietet er zumindest hier nicht." Soorgelyke standpunte word gehandhaaf deur Bligh (1969:258), Esler (1998:187) en Morland (1995:204). 
- Schlier (1971:138) verwerp die idee dat 'n mens 'n ontbrekende premis soos "niemand kan die wet nakom" of "niemand kom ooit die wet in die praktyk na nie" moet byvoeg om sin te maak van die verhouding tussen vers $10 \mathrm{a}$ en $10 \mathrm{~b}$. In plaas daarvan gaan hy van die standpunt uit dat die aanhaling veronderstel dat die volle nakoming van die wet moontlik is en inderdaad plaasvind. Volgens hom is die enigste bedoeling wat Paulus met die aanhaling het, om die woord толүбаı te beklemtoon aangesien hy net wil aantoon dat dié wat die wet nakom, net fokus op doen en daarom vervloek is.

- Volgens Sanders (1983:21-22) is dit nie korrek om te aanvaar dat Paulus die woord $\pi \hat{e} \sigma \iota \nu$ in die aanhaling wil beklemtoon nie. Hy wys daarop dat 'n mens in gedagte moet hou hoe Paulus te werk gaan as hy sy aanhalings in Galasiërs 3 kies. In vers 10 wil hy 'n aanhaling gebruik om te wys dat "wet" met "vloek" geassosieer moet word. Die enigste plek waar so iets wel in die LXX voorkom, is in Deuteronomium 27:26 en daarom gebruik Paulus dié teks. Dus val die klem volgens Sanders in die aanhaling bloot op die verbinding van "vloek" en "wet" en nie op "alles" of "doen" nie.

- Martyn (1998:311) aanvaar dat Paulus genoodsaak is om Deuteronomium 27:26 te gebruik omdat hy weet dat sy opponente dit gebruik het. Dié teks het hulle perspektief natuurlik soos 'n handskoen gepas: die Skrif sê as die Galasiërs nie wou doen wat die wet sê nie, is hulle vervloek. Volgens Martyn haal Paulus die teks aan net soos dit is, maar pas hy dit op ' $n$ heeltemal ander manier toe as wat sy opponente dit gedoen het: volgens Paulus is hulle wat die wet nakom, dié wat volgens dié teks vervloek is. Op dié manier verwyder Paulus volgens Martyn die onderskeid tussen dié wat die wet nakom en dié wat nie die wet nakom nie en probeer hy eintlik sê dat almal onder die vloek van die wet is.

- Garlington (1997:85-121) bespreek Paulus se hantering van OuTestamentiese aanhalings in Galasiërs 3:10-13 vanuit wat hy noem die "role reversal" wat plaasgevind het in die lig van die Christusgebeure. Oorspronklik het al die tekste gefunksioneer binne kontekste waarin dit gegaan het oor die onderskeid tussen getrouheid en ontrouheid aan God. In sy hantering van die tekste keer Paulus nou egter die rolle om: sy opponente wat wel die wet nakom, word van ontrouheid aan God beskuldig. Spesifiek in die geval van Deuteronomium 27:26 gebruik Paulus volgens Garlington die teks op 'n ironiese manier om die effek van "role reversal" te bewerkstellig: deur alles te doen wat die wet vra, is die opponente besig om eintlik nie alles te doen wat die wet vra nie, want hulle kom die wet nie op so 'n manier 
na dat die eskatologiese bedoeling van die wet tot sy reg kom nie, dit wil sê dat die wet wys na Jesus van Nasaret wat al die skeidsmure tussen volkere opgehef het.

Die feit dat daar so 'n wye reeks standpunte is oor die vraag in watter sin Paulus Deuteronomium 27:26 as 'n ondersteuning van sy standpunt in vers 10a sien, bevestig net hoe moeilik dit is om 'n keuse te maak wanneer 'n mens Galasiërs 3:10 interpreteer. Hoe kies 'n mens tussen al die interpretasies? Myns insiens is daar twee belangrike riglyne wat kan help om by 'n goed verantwoorde interpretasie uit te kom.

\section{Die manier waarop Paulus aanhalings kies}

Die eerste riglyn het te doen met 'n keuse oor die manier waarop Paulus aanhalings kies en aanwend. Dit is belangrik om raak te sien dat die rede vir al die verskillende interpretasies van die verband tussen vers 10 en die aanhaling verband hou met die feit dat Deuteronomium 27:26 op die oog af die teenoorgestelde sê as wat Paulus in 10a sê. Sy stelling in vers 10a lui dat diegene wat die werke van die wet nakom, vervloek is. Die aanhaling lui egter dat dié wat nie alles doen wat in die wet geskryf is nie, vervloek is. Die implikasie hiervan is dat dié wat wel alles doen wat die wet sê, nie vervloek is nie. Op die oog af lyk dit dus of die aanhaling nie direk in verband te bring is met Paulus se stelling in 10a nie. Hier moet 'n mens 'n fundamentele keuse maak: sou Paulus 'n teks aanhaal om iets te bewys terwyl hy goed besef dat dit eintlik presies die teenoorgestelde sê as wat hy wil bewys? As 'n mens hierop "ja" antwoord, kan 'n mens die opsies van Schlier, Sanders, Martyn en Garlington (soos hierbo uiteengesit), as moontlikhede oorweeg aangesien hulle almal in ' $n$ mindere of meerdere mate aanvaar dat Paulus die teks aanhaal om vers 10 a te bewys, maar dat dit nie werklik is wat die teks sê nie. Volgens Schlier wou Paulus net sê dat almal wat die wet "doen", vervloek is, maar die aanhaling sê tog die teenoorgestelde, naamlik dat die wat "nie die wet nakom nie", vervloek is. Volgens Martyn weet Paulus wat die teks eintlik sê, maar pas dit dan op die opponente toe - wat wel die wet nakom. Weer eens word die teks dus gebruik om die teenoorgestelde te sê as wat dit klaarblyklik bedoel. Volgens Sanders kies Paulus die teks bloot omdat dit die enigste teks is waarin die begrip "wet" met "vloek" geassosieer word en is die inhoud van die aanhaling nie vir Paulus werklik ter sake nie. Volgens Garlington weet Paulus dat die teks eintlik die teenoorgestelde sê as wat hy besig is om te sê, maar gebruik hy die teks op 'n ironiese wyse. (Hierop sou 'n mens kon reageer deur te sê dat Paulus se ironie dan klaaglik misluk het, aangesien dit vir byna 20 eeue lank misgekyk is!) Die probleem met enige een van hierdie interpretasies is dat 'n mens dan moet aanvaar dat Paulus willens en wetens 'n teks aanhaal om iets te bewys wat hy self goed weet die teks 
nie bewys nie. So 'n standpunt lyk egter onhoudbaar. Die bedrewe manier waarop Paulus aanhalings in die res van Galasiërs en ook in sy ander briewe gebruik, getuig hiervan. Dus sou dit beter wees om as riglyn vir 'n mens se interpretasie te aanvaar dat Paulus die teks aanhaal omdat dit vir hom op een of ander manier logies verband hou en as bewys dien vir dit wat hy in vers 10 a sê. Indien hierdie keuse korrek is, bly daar slegs twee opsies as moontlike keuses oor:

- dat niemand die wet kan hou nie en

- dat niemand in die praktyk die wet hou nie.

Die logiese verband wat Paulus gevolglik tussen sy stelling in vers $10 \mathrm{a}$ en die aanhaling sien, is dan: almal wat uit die werke van die wet is, is vervloek, want óf hulle kom nie die wet ten volle na nie, óf hulle kan nooit die wet ten volle nakom nie. Om tussen hierdie twee opsies te kies, moet 'n mens dan die vraag vra: Wat is Paulus se siening oor die vraag of 'n mens die wet ten volle kan nakom? Dit bring ons by 'n tweede riglyn.

\section{Onderskeid tussen inligting in die Galasiërbrief en die ander Pauliniese briewe}

As tweede riglyn is dit belangrik dat ' $\mathrm{n}$ mens moet onderskei tussen inligting wat uit die Galasiërbrief kom en inligting wat uit die ander Pauliniese briewe kom. In die Galasiërbrief spreek Paulus homself nêrens eksplisiet uit oor die vraag of 'n mens die wet ten volle kan nakom nie. Uit Galasiërs 3:10 kan 'n mens dus hoogstens aflei dat "die mense uit die werke van die wet" onder die vloek is omdat hulle nie die wet ten volle nakom nie. In die res van hierdie perikoop (Galasiërs 3:614) en ook in die ander gevalle in die Galasiërbrief waar Paulus regverdiging deur die wet afwys (byvoorbeeld 2:15-21; sien ook 5:3 en $6: 13)$, sê hy nooit dat dit vir mense onmoontlik is om die wet ten volle na te kom nie.

Die ander Pauliniese briewe help 'n mens ook nie om 'n besliste keuse te maak nie, want die inligting dui nie alles in dieselfde rigting nie. In die Filippensebrief beskryf Paulus onder andere sy vroeëre lewe in die

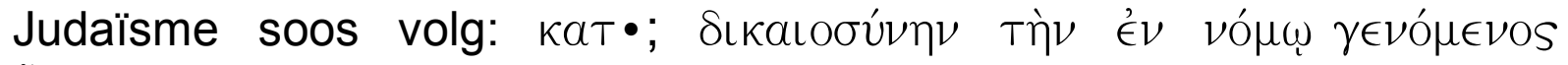
$a ́ \mu \in \mu \pi T O S$ ("wat die geregtigheid deur die wet betref, was ek onberispelik"; Filippense 3:6). Die woord ă $\mu \epsilon \mu \pi T o s$ ("onberispelik") wat Paulus gebruik, dui daarop dat hy (volgens Joodse standaarde) die wet ten volle nagekom het. (Kyk O'Brien 1983:134-135; Gnilka 1976:191 en Grundmann 1967:573 vir vollediger besprekings.) As 'n mens dus Galasiërs 3:10 in die lig hiervan sou interpreteer, sou dit beteken dat Paulus nie gedink het dit is vir mense onmoontlik om die wet ten volle na te kom nie (kyk byvoorbeeld Martyn 1998:310, Cranford 1994:243, Dunn 1993:243 
en Esler 1998:187), maar dat dit in die praktyk gewoonlik gebeur dat mense nie die wet ten volle nakom nie. 'n Mens sou dan verder kon bespiegel dat hy hier baie konkreet dink: sy opponente in Galasië wie se hele bestaan as 't ware wentel om die nakom van die wet, doen nie alles wat die wet sê nie en daarom is hulle vervloek. Galasiërs 6:13 sou dan goed kon aansluit by hierdie perspektief waarin Paulus spesifiek sê dat sy opponente nie die wet nakom nie.

Aan die ander kant is dit egter ook waar dat daar gedeeltes in die ander Pauliniese briewe is wat ' $n$ ander perspektief op die saak bied. In Romeine 3:1-20 beklemtoon Paulus die mensdom se inherente geneigdheid om sonde te doen waaruit 'n mens die afleiding kan maak dat dit nie vir mense moontlik is om die wet ten volle na te kom nie (alhoewel Paulus dit nêrens eksplisiet so stel nie). Indien 'n mens Galasiërs 3:10 vanuit hierdie perspektief sou interpreteer, sou 'n mens dan kon sê dat "die uit die werke van die wet" vervloek is omdat niemand die wet ten volle kan nakom nie.

Om saam te vat: indien 'n mens jou interpretasie van Galasiërs 3:10 slegs baseer op dit wat in die Galasiërbrief staan, is die enigste wat 'n mens met sekerheid kan sê dat Paulus dink "die uit die werke van die wet" is vervloek omdat hulle in die praktyk nie die wet ten volle nakom nie. Indien 'n mens die inligting uit die ander Pauliniese briewe verreken, sal dit afhang aan watter briewe 'n mens voorkeur gee. Indien 'n mens voorkeur gee aan 'n gedeelte soos Romeine 3:1-20, sou die interpretasie van Galasiërs verder gaan: "die uit die werke van die wet" is vervloek omdat hulle nie die wet ten volle nakom nie en in elk geval ook nooit die wet ten volle kan nakom nie. Indien 'n mens egter voorkeur aan Filippense 3:6 sou gee, sal die interpretasie anders lui: alhoewel dit moontlik is om die wet ten volle na te kom, is "die uit die werke van die wet" (en dan spesifiek Paulus se opponente in Galasië en ook die Christene in Galasië wat hulle leer aanvaar) vervloek omdat hulle in die praktyk nie die wet ten volle nakom nie. Hierdie interpretasie sluit dan aan by Paulus se verwyt in Galasiërs 6:13 dat sy opponente nie die wet nakom nie.

\section{Die retoriese funksie van Galasiërs 3:10}

Noudat 'n keuse gemaak is ten opsigte van die moontlike betekenis van hierdie vers, kan die retoriese funksie van die vers binne die Brief aan die Galasiërs ondersoek word. Soos reeds in die inleiding vermeld, is hierdie vers deel van die groter perikoop 3:6-14. Paulus se basiese retoriese strategie in hierdie gedeelte is om argumente uit die Skrif (dit wil sê die Ou Testament) te gebruik om sy hoorders te probeer oortuig. Dit is die eerste keer in die Galasiërbrief dat Paulus so 'n reeks aan- 
halings uit die Skrif gebruik om die argumente van sy opponente te weerlê. ${ }^{3}$ Voordat die spesifieke manier waarop Paulus die soort argument hier gebruik, bespreek word, moet net enkele opmerkings gemaak word oor die manier waarop Paulus hierdie soort argument gewoonlik gebruik. Stanley (1998:700-730) het 'n deeglike studie van die saak gemaak. Ek lig enkele van sy bevindinge uit:

- Wanneer Paulus 'n beroep op die Skrif doen, is dit gebaseer op die veronderstelling dat dit die laaste woord oor 'n saak is omdat dit alle menslike gesprek en debat transendeer.

- Paulus plaas sy aanhalings uit die Ou Testament gewoonlik binne goed gestruktureerde argumente sodat die bedoeling van die aanhalings (volgens sý interpretasie) duidelik is.

- Paulus pas soms die bewoording van 'n aanhaling effens aan om sy argument beter te pas.

- In die geval van die Galasiërbrief het hy na alle waarskynlikheid verwag dat sy gebruik van die Skrif sy eie posisie binne die geledere van die Christene in Galasiërs sou versterk omdat dit die band waarmee hulle gesamentlik aan die God van Israel gebind is, sou verinnig.

- Vermoedelik het Paulus ook gehoop dat die bedrewenheid waarmee hy die Christene se heilige teks uitlê, sy lesers in Galasië gunstig teenoor hom sou stem.

In die geval van Galasiërs 3:6-14 is dit belangrik om raak te sien dat Paulus deurgaans gebruik maak van argumente uit die Skrif, maar dit telkens op 'n ander manier aanwend:

- In verse 6-9 gebruik hy aanhalings uit Genesis vanuit sy perspektief om sy opponente se interpretasie van Abraham te weerlê. Volgens Paulus toon Genesis 15:6 dat Abraham geregverdig is omdat hy geglo het. Dit bewys dat almal wat glo, kinders van Abraham is. Verder argumenteer Paulus dat God in Genesis 12:3 en 18:18 aan Abraham belowe het dat alle nasies in hom geseën sou word. Dit beteken volgens Paulus dat almal wat glo, in Abraham geseën sal word.

- In vers 10 - die vers waaroor dit in hierdie artikel gaan - gebruik Paulus 'n ander aanhaling, dié keer uit Deuteronomium 27:26, maar

3 Dit is moontlik dat Paulus in Galasiërs 2:16 ook sinspeel op 'n gedeelte uit die Ou Testament (Psalm 143:2), maar in daardie geval is dit nie die oorheersende retoriese strategie soos in Galasiërs 3:6-14 nie. 
dan nie bloot om die opponente te weerlê nie. Sy retoriese strategie word nou gedomineer deur twee ander sake:

\section{- Vilifikasie van sy opponente}

Die teks word gebruik as basis vir vilifikasie (swartsmeer) van sy opponente. Dit is nie die eerste keer dat Paulus hierdie strategie in Galasiërs gebruik nie. Hy het dit ook in Galasiërs 1:7 en 3:1 gebruik. Vilifikasie was 'n verskynsel wat wyd voorgekom het in die vroeë Christelike epistolografie (kyk Du Toit, 1994) en in die destydse Mediterreense samelewing. In hierdie geval is die spesifieke vorm van vilifikasie wat Paulus gebruik, sy beskrywing van sy opponente as mense wat vervloek is. Dit is belangrik om raak te sien dat Paulus nie in soveel woorde sê dat hy na die opponente

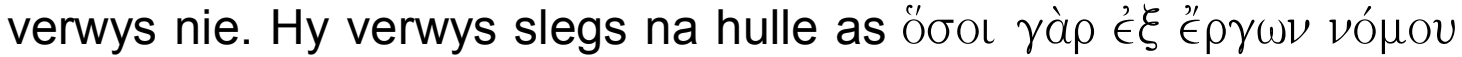
Ei $\sigma^{\prime} \nu$ ("die wat uit die werke van die wet is"), maar dít is die manier waarop vilifikasie gewoonlik in die vroeë Christelike epistolografie plaasgevind het. Du Toit (1994:406), wat verskeie ander voorbeelde bespreek waar Paulus dieselfde tegniek gebruik, is waarskynlik korrek as hy sê dat Paulus dit dalk doelbewus op hierdie manier doen omdat hy daardeur die indruk wil skep dat sy opponente 'n klein onbeduidende groepie is en/of negatiewe skaduagtige figure is. Alhoewel Paulus nie direk sê dat hy na sy opponente verwys nie, sou dit vir sy lesers glashelder gewees het dat hy na sy opponente verwys. Esler (1998:187) beskryf dit daarom tereg as "extreme and rigid stereotyping". Die effek wat Paulus hierdeur probeer verkry, is om die afstand tussen die Galasiërs en sy opponente te probeer vergroot sodat hulle minder geneig sal wees om die sieninge van die opponente te aanvaar.

\section{- 'n Retoriese dreigement}

'n Tweede tegniek wat Paulus in hierdie vers gebruik, kan beskryf word as 'n retoriese dreigement. Deur middel van die aanhaling en sy eie stelling waardeur die aanhaling vir die spesifieke situasie geïnterpreteer word, is Paulus nie net besig om sy opponente swart te smeer nie, maar is hy tegelykertyd op 'n subtiele manier besig om sy lesers te dreig dat hulle gevaar loop om onder die vloek van die wet te kom. Uiteraard is so 'n retoriese dreigement 'n baie sterk oorredingsmiddel en sou dit die Galasiërs twee keer laat dink het voordat hulle sy opponente se standpunte sou aanvaar.

Die dreigement wat Paulus hier in Galasiërs 3:10 uiter, is op 'n manier verwant aan die dubbele vloek wat Paulus in Galasiërs 1:89 uiter. Volgens Morland (1995:198-214) funksioneer Galasiërs 3:10 retories op dieselfde vlak as Galasiërs 1:8-9, dit wil sê as 'n 
retoriese vloek, maar myns insiens is dit nie die geval nie. Die dubbele vloek wat Paulus in Galasiërs 1:8-9 gebruik, is baie sterker geformuleer as die dreigement wat Paulus in Galasiërs 3:10

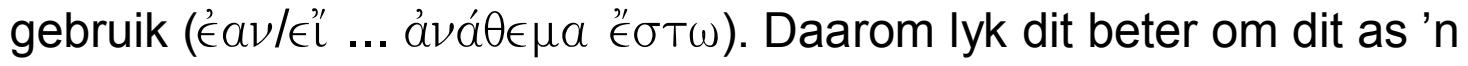
retoriese dreigement en nie as 'n retoriese vloek nie te klassifiseer.

- In verse 11-12 gebruik Paulus aanhalings uit Habakuk 2:4 en Levitikus 18:5. Hierdie keer fokus sy retoriese tegniek weer op die weerlegging van sy opponente se standpunt. Dit is egter nie gerig op die vraag oor die kindskap van Abraham soos in die geval van verse 6-9 nie, maar spesifiek op die saak van regverdiging deur die wet al dan nie. Paulus gebruik hierdie twee tekste om aan te toon dat regverdiging nie deur die nakoming van die wet kan kom nie, maar slegs deur die geloof.

- In vers 13 gebruik Paulus weer 'n teksvers uit Deuteronomium hierdie keer uit Deuteronomium 21:23. Sy bedoeling hier is om te bevestig dat die manier waarop Christus gesterf het, bewys dat hy as 'n vervloekte gesterf het. Hierdie aspek word dan gebruik as rugsteun vir sy stelling dat Christus vervloek is om Christene van "die vloek van die wet" te bevry. Met hierdie uitdrukking gryp Paulus terug na vers 10 en na alle waarskynlikheid is die onderliggende argument dat dit dus onnodig vir die Galasiërs is om die wet te probeer doen en so die gevaar te loop om aan die vloek van die wet onderworpe te wees.

\section{Samevatting}

Uit die bespreking het dit geblyk hoe moeilik dit is om Galasiërs 3:10 te interpreteer. Daar is aangetoon dat eksegete se interpretasie van die vers veral fokus op die volgende drie aspekte:

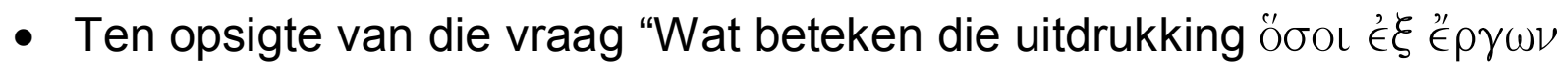

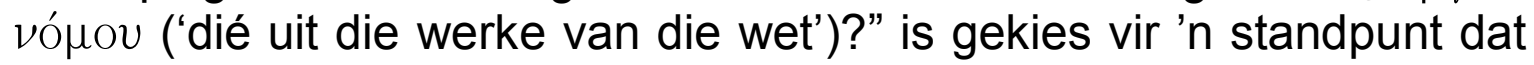
dit verwys na Paulus se opponente in Galasië as 'n groep mense wat die nakoming van die wet as van deurslaggewende belang beskou het vir 'n mens se verhouding tog God.

- Ten opsigte van die vraag "Wat beteken die uitdrukking ímò кaтápav ('onder 'n vloek')?" is gekies vir die interpretasie dat dit verwys na 'n dreigende vloek, 'n vloek wat sou kom oor elkeen wat nie alles doen wat die wet voorskryf nie.

- Ten opsigte van die vraag "Hoe moet die verband tussen Paulus se stelling in vers $10 \mathrm{a}$ en die aanhaling in vers $10 \mathrm{~b}$ verstaan word?" is geargumenteer dat dit die beste is om te kies vir ' $n$ interpretasie wat 
uitgaan van die veronderstelling dat Paulus die teksvers uit Deuteronomium 27:26 aanhaal omdat hy 'n logiese verband sien tussen sy stelling in vers $10 a$ en hierdie aanhaling. Daar is verder geargumenteer dat 'n mens op grond van die gegewens in die res van die Galasiërbrief die logiese verband soos volg kan verduidelik: "die mense uit die werke van die wet" is onder die vloek omdat hulle nie alles doen wat in die wet geskryf is nie. Daar is ook aangetoon dat 'n mens hierdie perspektief verder kan verfyn in die lig van gegewens uit die ander Pauliniese briewe, maar dat die spesifieke manier waarop 'n mens dit dan doen, beïnvloed word deur die vraag aan watter gegewens 'n mens dan voorkeur gee in die ander Paulusbriewe.

Ten opsigte van die retoriese funksie van vers 10 is aangetoon dat Paulus hierdie vers op twee maniere aanwend, naamlik, eerstens, as basis vir vilifikasie van sy opponente, en, tweedens, as retoriese dreigement om te probeer verhoed dat sy lesers die standpunt van sy opponente aanvaar.

\section{Bibliografie}

BECKER, J. 1981. Der Brief an die Galater. Göttingen : Vandenhoeck \& Ruprecht.

BETZ, H.D. 1979. Galatians. A commentary on Paul's Letter to the churches in Galatia. Philadelphia : Fortress.

BLIGH, J. 1969. Galatians. A discussion of St. Paul's epistle. London : St. Paul Publications.

BONNEAU, N. 1997. The logic of Paul's argument on the curse of the law in Galatians 3:10-14. Novum Testamentum, 39(1):60-80.

BRASWELL, J.P. 1991. 'The blessing of Abraham' versus 'the curse of the Law': another look at Gal. 3:10-13. Westminster Theological Journal, 53(1):73-91.

BURTON, E. de W. 1962. A critical and exegetical commentary to the Epistle of the Galatians. Edinburgh : Clark.

CRANFORD, M. 1994. The possibility of perfect obedience: Paul and an implied premise in Galatians 3:10 and 5:3. Novum Testamentum, 36(3):242-258.

DU TOIT, A.B. 1994. Vilification as a pragmatic device in early Christian epistolography. Biblica, 75(3):403-412.

DUNN, J.D.G. 1990. Jesus, Paul and the law. Studies in Mark and Galatians. London : SPCK.

DUNN, J.D.G. 1993. The Epistle to the Galatians. Peabody : Hendrickson.

ECKSTEIN, H.-J. 1996. Verheißung und Gesetz. Eine exegetische Untersuchung zu Galater 2,15-4,7. Tübingen : Mohr.

ESLER, P.F. 1998. Galatians. London : Routledge.

GARLINGTON, D.B. 1997. Role reversal and Paul's use of Scripture in Galatians 3:10-13. Journal for the Study of the New Testament, 65(1):85-121.

GNILKA, J. 1976. Der Philipperbrief. Freiburg : Herder.

GRUNDMANN, W. 1967. $\mu \epsilon ́ \mu \phi о \mu a \iota \kappa T \lambda$. Theological Dictionary of the New Testament. 4. Grand Rapids : Eerdmans. p. 571-574.

HÜBNER, H. 1993. Biblische Theologie des Neuen Testaments. Band 2: Die Theologie des Paulus und inre neutestamentliche Wirkungsgeschichte. Göttingen : Vandenhoeck \& Ruprecht. 
$\mathrm{KOCH}$, D.-A. 1986. Die Schrift als Zeuge des Evangeliums. Untersuchungen zur Verwendung und zum Verständnis der Schrift bei Paulus. Tübingen : MohrSiebeck.

LIETZMANN, D.H. 1971. An die Galater. Tübingen : Mohr.

LONGENECKER, R.N. 1990. Galatians. Dallas : Word.

MARTYN, J.L. 1998. Galatians. A new translation with introduction and commentary. New York : Doubleday.

MORLAND, K.A. 1995. The rhetoric of curse in Galatians. Paul confronts another Gospel. Atlanta : Georgia.

MUSSNER, F. 1977. Der Galaterbrief. Freiburg : Herder. Dritte, erweiterte Auflage.

NOTH, M. 1957. Die mit des Gesetzes Werken umgehen, die sind unter dem Fluch. (In Noth, M. Hrsg. Gesammelte Studien zum Alten Testament. München : Kaiser. p. 155-171.)

O'BRIEN, P.T. The epistle to the Philippians. A commentary on the Greek text. Grand Rapids : Eerdmans.

ROHDE, J. 1989. Der Brief des Paulus an die Galater. Berlin : Evangelische Verlagsanstalt.

SANDERS, E.P. 1983. Paul, the law, and the Jewish people. Philadelphia : Fortress.

SASS, G. 1995. Leben aus den Verheissungen. Traditionsgeschichtliche und biblisch-theologische Untersuchungen zur Rede von Gottes Verheissungen im Frühjudentum und beim Apostel Paulus. Göttingen : Vandenhoeck \& Ruprecht.

SCHLIER, H. 1971. Der Brief an die Galater. Berlin : Evangelisches Verlag.

SCHREINER, T.R. 1984. Is perfect obedience to the law possible? A re-examination of Galatians 3:10. Journal of the Evangelical Theological Society, 27(2):151160.

SCHREINER, T.R. 1985. Paul and perfect obedience to the law: an evaluation of the view of E.P. Sanders. Westminster Theological Journal, 47(2):245-278.

SMIT, J. 1984. Naar een nieuwe benadering van Paulus' brieven. De historische bewijsvoering in Gal. 3:1-4:11. Tijdschrift voor Theologie, 24(3):207-234.

STANLEY, C.D. 1990. 'Under a curse': A fresh reading of Galatians 3:10-14, New Testament Studies, 36(4):481-511.

STANLEY, C.D. 1998. Biblical quotations as rhetorical devices in Paul's Letter to the Galatians. Society of Biblical Literature 1998 Seminar Papers. p. 700-730.

THIELMAN, F. 1989. From plight to solution. A Jewish framework for understanding Paul's view of the law in Galatians and Romans. Leiden : Brill.

THURÉN, L. 2000. De-rhetorizing Paul. A dynamic perspective on Pauline theology and the law. Tübingen : Mohr-Siebeck.

WRIGHT, N.T. 1992. The climax of the covenant. Christ and the law in Pauline theology. Minneapolis : Fortress.

YOUNG, N.H. 1998. Who is cursed - and why? (Galatians 3:10-14). Journal of Biblical Literature, 117(1):79-92. 


\section{Kernbegrippe:}

Galasiërs 3:10

Pauliniese teologie

retoriek

wet

\section{Key concepts:}

Galatians 3:10

law

Pauline theology

rhetoric 